\title{
The effect of escalation of commitment and project risk in resources allocation decision
}

\author{
Astrid Febriana Loru Ngara Ledewara, Intiyas Utami* \\ Faculty of Economics and Business, Universitas Kristen Satya Wacana, Salatiga, Indonesia \\ *Corresponding Author e-mail: intiyas@staff.uksw.edu
}

A R T I C LE IN F O

Article history:

Available online

Keywords:

decision making, escalation of commitment, project risk

DOI: https://doi.org/10.20885/jaai.vol23. iss1.art6
A B S T R A C T

This research aims to examine the causal relationship between escalation of commitment and project risk with decision making in resource allocation (production cost). In this research the allocation of resources is in determining the cost of direct labor and material costs. To trigger cognitive dissonance, the determination of higher labor costs will increase the bonus of individuals working as production managers. When kos production has been set in a certain number, labor costs are high, while factory overhead costs is fixed, cause material costs to be low. The lower the material cost, the lower the product quality. Escalation of commitment is a condition when individuals already know the potential risks in the future, but still take risks for their decisions. This study proposes that the production cost allocation decision in conditions of high commitment escalation will tend to choose decisions that benefit themselves compared to when the escalation of commitment is low (choosing a labor cost allocation is higher than the material cost). This research also predicts that individuals in the face of high-risk projects will tend to allocate resources that benefit themselves. In addition, the interaction of the existence of a low level of escalation of commitment and a low risk project level will reduce the allocation of production costs to direct labor costs. This research uses a laboratory experiment design with 102 accounting students at a private university in Central Java who act as production managers with paper and pencil test. This experiment uses a $2 \times 2$ between subject. The results of the research show that there is a causal relationship between the escalation of commitment and the allocation of human resources and there is a causal relationship between the escalation of commitment and project risk. This finding also shows that there is an interaction between escalation of commitment, project risk and resource allocation decisions.

\section{Introduction}

The allocating resources decisions are important because of their impacts on a firm's value (Merchant \& Stede, 1997). There is a consideration that all of the individuals' decisions have a bounded rationality. Bounded rationality models by Simon (1995), however, argued that decision makers be subject to various decision biases. Moreover the extensive empirical evidence show that individuals and group choices, more often than not, violate rationality assumptions. There are three common constraints that influence human psychological limitation which are the set alternatives open to choice, the relationships that determine the pay-off such kind goal attainment, and the preference-orderings among pay-offs. The body of literature has participated in developing the research of escalation of commitment (EOC), part of the decision that explains the irrationality of individuals decision-making.

Individuals as decision makers often have to make an important and difficult decision under escalation situations in which loss has resulted from prior decision (Wong, 2005). EOC reflects an irrationality tendency of overinvesting resources (money, time, energy) in a failing course of action because decision makers fail to ignore the past costs as irrelevant in judging the future prospects for a particular decision (Curseu et al. 2016). The literature on mental accounting (Soman, 2001), explained EOC, the easier the budget of a particular resource is, the more likely decision makers will overcommit to a failing course of action. Wong (2005) explained escalation dilemma that is divided in several choice with losses and an uncertain choice with extreme consequences. Brockner (1992) identifies escalation as the tendency for decision makers to persist with failing courses of action. Another study explained that escalation effects are instances in which decision makers continue to commit resource to a losing course of action, solely because prior resource allocations have been made (Tan \& Yates, 2002). 
Moreover, this study will also be focusing on the effect of project risk on individuals decision-making in allocating resources. The previous study shows that individuals perception of a risk (level of certainty and or ambiguity) affect the decision of selection (Nahartyo \& Utami, 2014). The level of project risk is the main important factor, determining on how many resources are allocated. To explain escalation and project risk more completely, researcher invoke prospect theory perspective at the individuals level. In prospect theory, particularly people underweight outcomes that are merely probable in comparison with outcomes that are obtained with certainty (Kahneman \& Tversky, 1979).

There have been some studies examined EOC and project risk. The activities that relate to project risk is also considered affect on EOC. Yet, project risk researches have not considered EOC as part of them. Regarding management accounting, this research compares the decision-making made by individuals who have a low level of EOC and others with high level of EOC. Hence, there is a research question relating to EOC in decision-making: Whether the decision-making made by individuals who have a low level of EOC be different from others who have a high level of EOC? Besides EOC, project risk also plays a major role in this research. Project risk has considerable effect in individuals decision-making too. The previous study shows that the research needs a further study, especially in using extreme options in comparing project risks (Nahartyo \& Utami, 2014). The objective of the research is to continue the previous research that compares individuals decision-making in a low project risk and a high project risk. Thus, the next research question: Whether the individuals decision depend on low and high project risks?

Thus, it is important to better understand the effect of EOC and project risk to the individuals decision. First, the purpose of this study is to fill the gap by examining EOC how EOC relates to project risk. The second purpose of this study is to extend the previous study in relation to the altering rationality in decision-making including EOC and project risk. Therefore, the main aim of this paper is to test the effect of EOC and project risk to resource allocation decision. This research is expected to contribute to the management accounting literature. First, the impact of EOC in directing personal perception on the resource allocation decisions. Second, it is expected to give suggestion how to encourage employees in dealing with projects that can decrease the current financial benefit, yet have the potential organizational benefits in the future.

This research used a laboratory experimental design work on experiment module. The subjects consisted of a group of students who have taken a cost accounting class and act as production manager of the production department of an international company. This research also designed the subjects to have an opportunity to get incentives based on the choice of the resource allocations decision (cost accounting). The higher the direct labor cost chosen, the higher incentive the participants will get. The incentives offered, change the decision to acquire part of a larger resource. First, the participants were divided into two groups of project risk conditions (low and high). Then, they were asked to allocate the production cost in raw material cost and direct labor cost, while overhead cost is fixed. The decision was given in a low EOC condition. The next stage, the participants were asked to make the same decision with the high EOC condition. This experiment employed $2 \times 2$ factorial design betweensubjects factor.

The phenomenon shows that many Small Medium Enterprise (SMEs) entrepreneurs make high-risk decisions, for example in terms of investment decisions and funding decisions. 78\% of MSMEs cannot manage their business properly, for example because there is no good bookkeeping (Sindonews.com, 2018). The absence of bookkeeping encourages MSME entrepreneurs to make careless decisions, for example, dare to take credit or invest without good consideration.

The rest of this paper will be divided into four sections. I first introduce and review literature on prospect theory, decision-making, and how EOC and project risk effect decision makers or decision-making. From those theories, there will be three hypotheses derived that are next described. Second, as previously mentioned I will explain the research methodology in conducting this experimental researh. Third, I discuss the results and finally, I conclude with a general discussion and offer directions for future research.

\section{Literature Review}

In this study the presence of EOC and project risk are altering the allocation decision. These variables are selected for important theoritical basis and are generally used in practice and research (Tan \& Yates, 2002; Nahartyo \& Utami, 2014). Tan and Yates (2002) show that escalation effects occur among experienced participants even when explicit future costs and benefit provided. In particular, the previous study discusses the potential influence of financial budgets on such escalation effects. Moreover, Nahartyo and Utami (2014) also provide an overview of how project risk will participate and contribute in making allocation decisions. As mentioned previously, this research will also use prospect theory to explain EOC and project risk. 


\section{Prospect Theory}

Kahneman and Tversky (1979) present a critique of expected utility theory as a descriptive model of decision making under risk and develop an alternative model, which they call prospect theory. Prospect theory suggests that managers use a reference point (target) to choose among alternatives (Kahneman \& Tversky, 1979). Moreover, in this theory, there are certainty effect and isolation effect. Certainty effect means people underweight outcomes that are merely probable in comparison with outcomes that are obtained with certainty. On another hand, isolation effect means people generally discard components that are shared by all prospects under consideration.

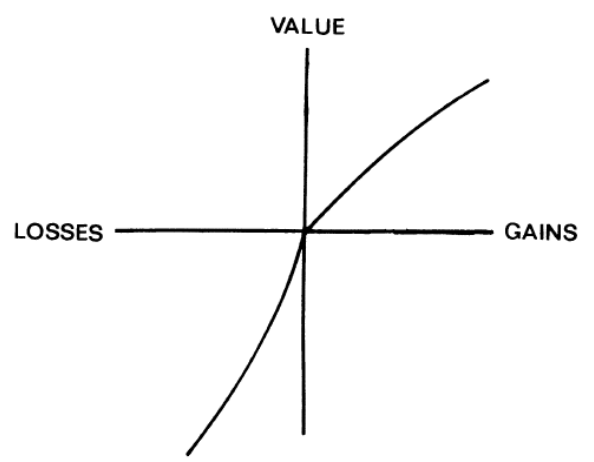

Figure 1. A hypothetical value function

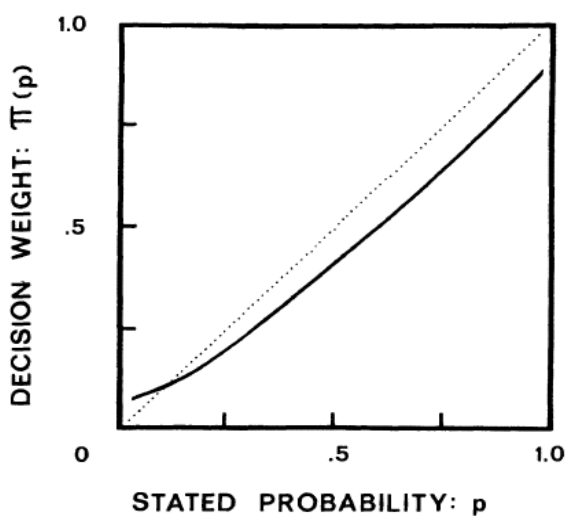

Figure 2. A hypothetical weighting function

In general, outcomes below the target point are evaluated as losses, and outcomes above it are evaluated as gains (Chang et al. 2002). Individuals have irrational tendency to be less willing to gamble with profits than with losses (Tvede, 1999). In its original form, it is concerned with behavior of decision makers who face a choice between two alternatives. Thus, decision subject to risk are deemed to signify a choice between alternative actions, which are associated with particular probabilities (prospects) or gambles. Regarding to Kahneman and Tversky (1979) the present analysis of preference between risky options has developed two themes. First theme concerns on editing operations that determine how prospects are perceived, and second theme involves the judgmental principles that govern the evaluation of gains and losses and the weighting of uncertain outcomes.

\section{Resources Allocation Decision-Making}

Chang et al. (2002) review the following four decision maker-related factors (part of factors that affecting managers' resource allocation judgments): knowledge and academic training, domain-specific experience, and psychological factors (eg cognitive characteristics and risk propensity). Academic instruction has three major effects: it makes individuals aware of decision rules, it reinforces decision rules by providing examples; and it increases the likehood that proper decision rules will be utilized (Tan \& Yates, 1995). Chang and Ho (2004) examine the adequacy of using undergraduate students as surrogates for experienced decision makers in resource allocation context. Undergraduate students and manager with extensive work had performed similarly on the test of their knowledge since at least they had a basic knowledge about sunk cost and opportunity cost. 
Psychology factors consist of cognitive characteristics and risk propensity. Managers' resource allocation may influenced by cognitive styles and cognitive abilities (Kogan, 2013). Cognitive styles are defined as distinctive ways of acquiring, storing, retrieving, and transforming information; they are consistent and rarely change. On the other hand, cognitive abilities relate to knowledge encoding and retrieval, and they are concerned with skill level. According to the previous research, the relationship between resource allocation judgments and decisions is an important part of the resource allocation process. Psychological limit of the organism (particularly with respect to computational and predictive ability), actual human rationality-striving can at best be an extremely crude and simplified approximation to the kind of global rationality that is implied (Simon, 1995).

\section{Escalation of Commitment and Its Effects}

According to Ruchala (1999) escalation involves the continuance of a failing course of action, sometimes described as "throwing good money after bad." The issue of whether individuals escalate because of shifts in risk attitude. The sunk cost effect is manifested in a greater tendency to continue an endeavor once in investment in money, effort, or time has been made (Arkes \& Blumer, 1985). Since the prior investment has been made, it is motivating the present decision to continue. Sunk costs are unrecoverable, so that they are perceived as reductions, or losses, relative to the individuals' reference point (Ruchala, 1999). Thus, the potential for recouping loss overshadows the costs of additional investments if the investment subsequently fails. This perception results in an increased willingness to take risks in an effort to recover loss.

In escalation situation, costs have been incurred in the pursuit of an objective that is unlikely to be achieved, regardless of future endeavors (Whyte, 1993). Thus, the difficulty in deciding whether to invest additional resources in a losing course of action in many cases, leads to a process of escalating commitment. The escalation literature has emphasised that choosing to persist is a relatively risky option that could lead to an uncertain outcome of eventual gains or more losses (Brockner, 1992). In the context of investment decision making it is stated that investment decision-making behavior is influenced by attitudes towards investment risk (Park et al. 2016). The escalation of commitment experienced by decision makers will encourage him to choose risky decisions.

In this study, when individuals are dealing with a low level of EOC conditions, there is a tendency to allocate the production cost more to the material cost. Otherwise, when individuals are dealing with a high level of EOC condition, they tend to allocate production cost more to the direct labor cost. It happens because when individuals as decision makers fail to ignore the past cost or loss, try to recover in a short term. By allocating more in direct labor cost, individuals will get more incentives. Therefore, it is hypothesized that:

H1: Subjects under a high level of EOC conditions will allocate more production cost to direct labor cost.

\section{Project Risk and Its Effects}

According to Dinu (2016) all projects have risks, projects might be at a high risk to complete as per schedule within budget and to meet the expected quality, if a probable risk of the project is not identified earlier. There is a controversy in understanding the concept of ambiguity and uncertainty. Ambiguity is not the same as uncertainty (Geersbro \& Ritter, 2010). Uncertainty is caused by lack of information and quality of information which is a source of ambiguity. That the ambiguity is placed as an adjunct of the probability distribution layer to two of the peaks possibility of uncertainty in a risky decision. Moreover, they examined how managers make investment choices when they face probabilistic ambiguity in decisions under the risk. They found that when managers are faced with imprecise probabilities, their perceptions of the risks involved influence their choice of either an ambiguous option (e.g., with a chance of success that falls within a wide percentage range) or unambiguous option (e.g., with a more precisely estimable chance of success). More specifically, managers tend to choose the least ambiguous option, especially when they perceive a big difference between two options. Not far from previous research, this research defined the project risk as accumulation of uncertainty and ambiguity in the effect of specific process, for example resource allocation project (Nahartyo \& Utami, 2014).

Chang et al. (2002) suggest related-projects (uncertainty), decision-making characteristics (knowledge and experience) and environmental managerial (eg information asymmetry affect resource allocation decisions). Making allocation decisions to be different between the project faced, subjectivity managers influenced by the uncertainty of future. The relationship between uncertainty and individuals subjectivity in preparing decisions become critical in determining the characteristics and effectiveness of resource (Nahartyo \& Utami, 2014). Individuals would prefer a probability than the range of probability. So, it can be concluded that individuals which are more ambiguous and face a higher project risk will be more concerned with self-interest in determining the choice. Since there is a selfinterest, individuals tend to allocate production cost more to direct labor cost because individual could get more incentives from that. Therefore, the following hypotheses is developed:

$\mathrm{H} 2$ : Subjects under a high level of project risk will allocate more production cost to direct labor cost. 
The Interaction Effect of Escalation of Commitment and Project Risk

Wong (2005) states the present study suggests that a complete theoretical model EOC should include risk as one of its major components. Moreover, previous studies have paid insufficient attention to the role of risk in escalation and simply acknowledge one single risk-related variable, problem framing, as one of the psychological determinants of escalation (Brockner 1992; Staw, 1997; Whyte 1993). As many as number of personal values that will be accepted through individuals effort, they are motivated to receive their incentive. Incentive generally is accepted by people in the form of salaries, bonuses, promotion and recognition for his achievement. In this study predicts that the high level of uncertainty/low level of ambiguity (a low level of risk project) will trigger individuals to pursue projects that lower the benefits received today but positively beneficial in the future. Managers have responsibility for a large project, the greater the responsibility they have, the greater the individual to change attitudes that motivate themselves to get what they want Self-justification theory predicts that managers will increase commitment to the project when feedback is not in accordance with the nature of the project designed from the start.

As mentioned previously, the implementation of EOC and project risk which is related to the prospect theory in the resources allocation decision, conclude that when individuals in a higher level of EOC tend to allocate production cost to direct labor cost rather than material cost. As well as EOC, a higher level of project risk, individuals tend to allocate production cost to direct labor rather than material cost. That means individuals might be value as assigned to gains and losses rather than to final assets; also probabilities are replaced by decision weights. In short, indivuals are motivated to gain more incentives to recover their prior decision that make them in loss condition. Therefore, it is hypothesized that:

H3: The existence of a low level of EOC and a low level of project risk will allocate less production cost to direct labor cost.

\section{Research Method}

This study used laboratory experiments. High internal validity is obtained from the experimental method to be superior in testing the causal relationship between the dependent variable which is altering rationality in decisionmaking and independent variables which are EOC and project risk. Experiment module was executed after a thorough examination of the first (pilot test). The module was developed from research experiments conducted by Nahartyo and Utami (2014) by modifying the project risks and adds EOC.

Design

The experiment employed $2 \times 2$ factorial design between-subject. The first factor is a high level and a low level of project risk. The second factor is high level and low level of EOC. They were randomly assigned to four treatment conditions. There are four conditions by crossing two EOC conditions with two project risk conditions. This experiment uses paper and pencil, a set of experimental modules printed by each experimental group in the same number of pages. Experimenting with computers is not a tool in this experiment because there is a risk of internet connections that have the potential to interfere with the experiment.

\section{Participant}

This research took 112 undergraduate students of economics and business faculty who have already taken cost accounting course as participants. It means that the participants are taking the management accounting course or other subjects that required cost accounting basic. The selection of subjects was done randomly, giving the subject the opportunity to get one of the experimental treatments. Randomization is done by dividing the experimental module randomly to the subject. The reason for choosing a subject has taken the Cost Accounting course is to understand the cost of production. The selection of subjects with this particular reason is because they use students as surrogates from practitioners (cost accounting managers).

The implementation of experiments is conducted by experiment-assistants who accompany participants to undertake the experiment module. Therefore, the experiment-assistants play an important role in explaining the role and duties of participants in the simulation of the cost accounting. In addition, the assistant experimenter has an important portion to isolate the participants to be serious and focused while doing the experiment module.

Demographic questions are given at the beginning of the experiment with the aim of getting initial information from the participants. Giving demographic information on the subject at the end of the experiment has the potential to forget the subject and refuse to fill out his identity. The potential of the Hawthorn effect was overcome because in the experimental module no subject name was asked. Other identities in the form of gender and age are needed so that in the experiment the randomization belief has been carried out effectively and not influenced by demographic characteristics. 
Table 1. Experimental Matriks

\begin{tabular}{ll|cc}
\hline & & \multicolumn{2}{|c}{ EOC Conditions } \\
& & Low & High \\
\hline \multirow{2}{*}{ Project Risk } & Low & Cell 1 & Cell 2 \\
& High & Cell 3 & Cell 4 \\
\hline
\end{tabular}

Information:

Cell 1: Low level of project risk with low level of EOC conditions

Cell 2: Low level of project risk with high level of EOC conditions

Cell 3: High level of project risk with low level of EOC conditions

Cell 4: High level of project risk with high level of EOC conditions

\section{Experimental Procedure}

This study assumes that the individuals are working in a production department which is international furniture company. Their duty to allocate production cost in three elements, namely materials, direct labor and overhead. Individuals know that they will get the benefit by maintaining direct labor cost on the maximum amount. Moreover, individuals also know that the material cost reduction will impact on the lower quality of the product. Overhead cost is designed as fixed cost. The decision of how individuals allocate higher direct labor cost indicate decisions above selfish interest.

The procedures comprise of eight steps as follow:

1. Participants are seated randomly and start to work on experiment module. The subjects receive 1 of 4 modules that have been prepared. The first subjects will receive modules on decision-making by the low level of project risk and a low level of EOC, the second subjects will receive a module containing about decision-making with a low level of project risk and a high level of EOC, the third subjects will be given a decision-making module that contains the high level of project risk and low level of EOC conditions, and the last subjects will receive a module containing a high level decision making of project risk and low level of EOC conditions. Subjects are informed that the subjects role is being a production manager at a company and the subjects are asked to answer a few questions from the module prepared by the examiner.

2. Participants are asked to fill in their identities containing their age, gender, grade point average (GPA), and semester. They are asked to fill out ten basic questions in the field of cost accounting and experimental research and should ensure that the subject is affected by the manipulation and not to test the ability of different accounting. Demographic questions are given at the beginning of the experiment with the aim of getting initial information from the participants. Giving demographic information on the subject at the end of the experiment has the potential to forget the subject and refuse to fill out his identity. The potential of the Hawthorn effect was overcome because in the experimental module no subject name was asked. Other identities in the form of gender and age are needed so that in the experiment the randomization belief has been carried out effectively and not influenced by demographic characteristics.

3. Cost accounting simulation starts with the presentation of a manufacturing company's profile by showing the image of the production process, the exhibition that is followed by the company and sample of products. The purpose of using the image is to internalize the participants in understanding the roles and duties. Some questions are then given to participants to obtain assurance that participants understand the roles and tasks assigned.

Then, the experiment module serves incentives earned by participants. The incentives will be in the form of dollars and are given by seeing the accuracy in answering questions in understanding the roles and tasks, the understanding of cost accounting, and the given manipulation (manipulation checks). Incentives in the form of "dollar" are also given based on the value of direct labor costs determined. The aim of giving incentives in the form of "dollar" is to test the self-interest of participants. If participants have a high self-interest, they will tend to ignore the long-term interests of the company to make decisions that benefit themselves in the short term. Participants are given a case in the form of dollars because the company designed in the experiment is an export company which in practice determines the cost of production in dollar terms. The use of dollars in determining the allocation of production costs as a form of ecological validity in experiments.

4. The next phase, the participants receive information tasks to be done by the head of the company that orders to determine production cost component order from a foreign buyer. Participants are asked to allocate $\$ 2.400$ to the three components, namely production costs, material costs, direct labor costs, and overhead cost. Overhead cost is already set at $\$ 500$, while material cost and direct labor cost can be selected from the range of $\$ 100$ - $\$ 1,000$. The higher the value material costs, the better the quality of the material. The higher the 
value of direct labor costs selected, the higher incentive participants obtained. In the final stage of this manipulation, participants received a question of checking manipulation.

5. Next, the director explains that to win the competition with other suppliers, the determination of foreign buyers production costs order is set not more than $\$ 2,000$. In the first group, participants are informed that the project failure rate is $20 \%$ (low risk) and the other group is informed that the project failure rate is $60-80 \%$ (high risk). Furthermore, the participants are asked to reallocate material cost, direct labor rooming with a choice of values between $\$ 100-1000$, while the value of fixed overhead cost $\$ 500$. The purpose of giving this manipulation is to investigate the process of changing the decision-making that force participants to choose to reduce material cost or direct labor cost. If they prefer reducing the material cost where at a previous stage already determined material costs at a higher level, then the participants are likely to have their own high interest. However, if participants tend to reduce the direct labor cost and maintaining high material, it can be interpreted that the participants give more emphasis on quality and long-term interests of the company than self-interest received in the form of incentives.

6. The next stage is similar to the previous procedure, except there is an information that the project has already started and there is some information related to the total cost incurred to date. Participants in high level of EOC condition know that they got losses but still continuing the project although they get loss. As a decision maker, the production manager should think whether takes the sustainability of the project and the importance of maintaining the quality of order fit the firm's mission. It is expected that participants who initially have more high self-interest would change their opinions.

7. The stage after the manipulation is the manipulation checks and obtaining information on the number of dollars they receive at the draw.

\section{Analysis Technique}

The first and second hypothesis tests are using the Test Independent t-test, the third hypothesis test is using the Test of Two-Way ANOVA (Analysis of Variance). The first and second hypothesis is testing the main effect, while the third hypothesis is testing the effect of the interaction. The hypothesis is supported if the significance value less than 0.05. Analysis of the data was based on literature review and test results.

\section{Results and Discussion}

\section{Manipulation Checks}

The experiment was conducted on May 15-16, 2017 in Accounting Management and Ethical Professional class, Economics and Business Faculty, Satya Wacana Christian University. The subjects consisted of 112 students from Economics and Business Faculty, Satya Wacana Christian University. From those 112 students, the experiment was conducted with manipulation checks and requirement checks. Requirement checks as the participant were conducted to ensure that the participants understood the tasks and role in cost accounting simulation and basic. The understanding of the tasks and role checking consisted of five questions, scoring 20 points each. The minimum scores of this checking were 60 points. As shown in Table 2, from 112 students as participants, all of them were scored above 60 points in understanding of the tasks and role checking.

The second checking was aiamed at knowing the participants' basic understanding of cost accounting. It consisted of five questions, scoring 20 points each and the minimum scores of this checking were 60 points. There were 10 out of 112 students who were scored below 60 points. Consequently, their data were not processed.

Table 2. Manipulation Checks

\begin{tabular}{llcc}
\hline Number & \multicolumn{1}{c}{ Description } & $\begin{array}{c}\text { Number of Qualified } \\
\text { Participants }\end{array}$ & $\begin{array}{c}\text { Number of Unqualified } \\
\text { Participants }\end{array}$ \\
\hline 1 & Qualified participants & 112 & - \\
2 & Tasks and role understanding checks (5 questions) & & 10 \\
3 & Cost accounting basic checks (5 questions) & & - \\
4 & Tasks and role understanding checks (3 questions) & 102 partcipants \\
\hline
\end{tabular}

Source: Primary Data

Table 3 shows the demography characteristics of participants including gender, GPA, age, and semester. Participants consisted of 40 males and 62 females with GPA average 3.00-3.50. The age of majority is 21-23 years old and most of the participants are from 6th semester. 
Table 3. Demography Characteristics of Participants

\begin{tabular}{lccc}
\hline Demography Characterictis & & Number of Participants & $\%$ \\
\hline Gender & Male & 40 & 39.2 \\
GPA & Female & 62 & 60.8 \\
& $<2.5$ & 8 & 7.8 \\
& $2,5-2,99$ & 21 & 20.6 \\
Age & $3,00-3,5$ & 51 & 50.0 \\
& $>3,5$ & 22 & 21.6 \\
Semester & $18-20$ years old & 45 & 55.1 \\
& 21-23 years old & 57 & 9.8 \\
& 4th semester & 10 & 78.4 \\
\hline
\end{tabular}

Source: SPSS Output Version 22

As shown in Table 3, subjects had diverse demography characteristics. In an experiment, randomization is effective, if it does not affect the decision of cost production. Statistic test was conducted, in order to prove that randomization is effective. Randomization testing was done by One Way ANOVA to see whether randomization has an effect or not on decision-making.

Testing the Hypotheses

Table 3 shows the statistic result of randomization test by using One Way ANOVA.

Table 1. Randomization Testing

\begin{tabular}{|c|c|c|c|c|c|c|}
\hline & & Sum of Squares & $\mathrm{df}$ & Mean Square & $\mathrm{F}$ & Sig. \\
\hline \multirow[t]{3}{*}{ GENDER } & Between Groups & $9,260.595$ & 1 & $9,260.595$ & 0.338 & 0.562 \\
\hline & Within Groups & $2,735,935.484$ & 100 & $27,359.355$ & & \\
\hline & Total & $2,745,196.078$ & & & & \\
\hline \multirow[t]{3}{*}{ GPA } & Between Groups & $118,940.349$ & 3 & $39,646.783$ & 1.479 & 0.225 \\
\hline & Within Groups & $2,626,255.730$ & 98 & $26,798.528$ & & \\
\hline & Total & $2,745,196.078$ & 101 & & & \\
\hline \multirow[t]{3}{*}{ AGE } & Between Groups & $13,897.833$ & 1 & $13,897.833$ & 0.509 & 0.477 \\
\hline & Within Groups & $2,731,298.246$ & 100 & $27,312.982$ & & \\
\hline & Total & $2,745,196.078$ & & & & \\
\hline \multirow[t]{3}{*}{ SEMESTER } & Between Groups & $65,529.412$ & 2 & $32,764,706$ & 12.10 & 0.302 \\
\hline & Within Groups & $2,679,666.667$ & 99 & & & \\
\hline & Total & $2,745,196.078$ & & & & \\
\hline
\end{tabular}

Source: SPSS Output Version 22

Based on Table 3, the demographic characteristics which are gender, GPA, age, and semester did not affect the decision-making (significant data above 0,05). It can be concluded that the decision-making taken by participants caused by manipulation which they accepted.

Independent T-test testing

Table 4 shows the statistic result of the first and second hyphotesis test by using Independent T-test.

Table 2. Independent Samples Test

\begin{tabular}{llcccc}
\hline & & Average & F & Sig & Sig \\
& & (Decision-making) & (2 tailed) \\
\hline Hypothesis 1 & Low level of EOC & 439.62 & 1.176 & 0.281 & 0.000 \\
& High level of EOC & 551.02 & & & 0.026 \\
\hline Hypothesis 2 & Low level of project risk & 456.86 & 2.472 & 0.119 & \\
& High level of project risk & 529.41 & & & \\
\hline Sumber: SPSS Output Version 22
\end{tabular}

Sumber: SPSS Output Version 22

Based on Table 4, the first hypothesis has significant value 0,000 and the second hypothesis has significant value 0,026 . Both hypothesis 1 and 2 have the significant value less than 0,05 . Thus, it can be said that both 
hypotheses were accepted. The level of EOC for hypothesis 1 and the level of project risk for hypothesis 2 affected the decision-making.

Two way ANOVA testing

Table 5 and 6 shows the statistic result of the third hyphotesis test by using Two Way ANOVA.

Table 3. The Results of Hypothesis 3

\begin{tabular}{lcc}
\hline \multicolumn{1}{c}{ Between-Subjects Factors } & Value Label & N \\
\hline EOC_LEVEL & LOW & 53 \\
& HIGH & 49 \\
PR_LEVEL & LOW & 51 \\
& HIGH & 51 \\
\hline
\end{tabular}

Table 6. Test of Between-Subjects Effects

Dependent Variable: Decision-Making

\begin{tabular}{lllrrr}
\hline \multicolumn{1}{c}{ Source } & \multicolumn{1}{c}{ Type III Sum of Squares } & df & Mean Square & F & Sig. \\
\hline Corrected Model & $507,341.092^{\mathrm{a}}$ & 3 & $169,113.697$ & 7.406 & 0.000 \\
Intercept & $24,434,193.93$ & 1 & $24,434,193.93$ & $1,070.021$ & 0.000 \\
EOC_LEVEL & $277,001.843$ & 1 & $277,001.843$ & 12.130 & 0.001 \\
PR_LEVEL & $105,426.201$ & 1 & $105,426.201$ & 4.671 & 0.034 \\
EOC_LEVEL*PR_LEVEL & $93,596.848$ & 1 & $93,596.848$ & 4.099 & 0.046 \\
Error & $2,237,854.987$ & 98 & $22,835.255$ & & \\
Total & $27,550,000.00$ & 102 & & & \\
Corrected Total & $2,745,196.078$ & 101 & & & \\
\hline
\end{tabular}

a. $\quad$ R Squared $=0.185$ (Adjusted R Squared $=0.160$ )

Based on Table 6, the result shows that the third hypothesis has a significant value 0.046 which is less than 0.05 . There were differences between participant decision in a low level of escalation commitment and low level of project risk with a high level of escalation commitment and high level of project risk. Thus, it can be said that the third hypothesis was accepted and affected the decision-making.

\section{Discussion}

\section{Escalation of commitment and its effects}

The first hypothesis predicted that subjects under a high level of EOC conditions will allocate more production cost to direct labor cost. This hypothesis was examined by using independent sample t-test. It is used for determining whether two samples which are not related have a different average. Independent sample t-test examined the direct labor cost in a low level of escalation commitment and high level of escalation commitment towards participants $(\mathrm{N}=102)$. The result shows that there was significant difference in direct labor cost in a low level of escalation commitment and high level of escalation commitment $(\mathrm{p}=0.000)$. This means that with a high level of escalation commitment, participants tend to be selfish in allocating more production cost to direct labor cost (551 in a high level of EOC and 440 in a low level of EOC). Therefore, the first hypothesis was accepted.

Moreover, this research consistent with the previous research about escalation commitment. Ruchala (1999) mentioned that a manager who has made a poor initial project decision can hide the error by continuing the failing course of action. It is supported by this experiment. When individuals had already known that they were fail in a previous investment, they persist to continue the project even if they know that they loss in previous investment. Individuals also escalate their investment because of the time completion that meet the closer a project is to being completed. This is consistent with the previous research which is conducted by Chang et al. (2002). They mentioned that the closer a project is to being completed, the more likely it is managers will continue the project. Thus, the project continuation which is taken by individuals is depend on based the level of escalation commitment whether they are in a low level of escalation commitment (there is no a pressure to continue the project from the firm) or high level escalation commitment (there is a pressure to continue the project from the firm). Furthermore, when they were in an almost the end of the project, they will tend to escalate their investment to recover in a short term (Ruchala, 1999). 


\section{Project Risk and Its Effects}

The second hypothesis predicted that the subjects under a high level of project risk will allocate more production cost to direct labor cost than subject under low level of project risk. It was also examined by using independent sample t-test. The result shows that probabilistic risk value is $0.026(p<0,05)$. The higher level of project risk is, the more tendency to allocate production cost to direct labor cost. Therefore, the second hypothesis was accepted.

This study is consistent with the previous study, showing that individual perception of a risk affects the decision of selection (Nahartyo \& Utami 2014). When participants in a high risk (60-80\% project failure) they tend to allocate more in direct labor than in a low risk, averaged 529 (high level of project risk) and 457 (low level of project risk).

In addition, this consistency supports Ho et al. (2002), mentioning individuals as production managers tend to choose the least ambigous option (more precisely estimable chance of success). When individuals in a low risk with the probability, they wiil allocate production cost more to material cost rather than when individuals in a high risk with the range of probability. Individuals which are more ambigous and face a higher project risk wiil be more concerned with self-interst in determining the choice.

The research findings also support Evaline (2010) that managers tend to avoid risk and take definite profits rather than face uncertain risks by stopping the project. Escalation of commitment is a behavior that often occurs in various social context problems. In organizations that design the right strategy, companies will face conditions that are not optimal because decision making is influenced by escalation of commitment.

\section{The interaction effect of escalation of commitment and project risk}

The third hypothesis stated that the existence of a low level of escalation commitment and low level of project risk will allocate less production cost to direct labor cost. It was examined by using two-way ANOVA. This examination was used to know the direct effects and moderate effects of escalation commitment and project risk to direct labor cost. The result shows that there were differences between participants' decision in a low level of escalation commitment combine with low level of project risk and high level of escalation commitment combine with high level of project risk. The significant value is $0.046(p \leq 0,05)$.

The interaction effect between escalation commitment and project risk comes to support individuals' decision-making in allocating resources. For situations in which escalation commitment is high and project risk is high, individuals will overcommit and take a greater incentive by allocating production cost more in direct labor cost. Moreover, individuals will try to recover their losses in the past. The higher project risk that occur in the past will lead them to take more incentive and to continue the previous investement. This results consistent with the prospect theory (Kahneman \& Tversky, 1979). which were individuals will be risk seeking such as they will prefer to allocate additional resources in the hope of turning the situation around, rather than to accept the sure loss if they were stop allocating resources at that point.

Escalation of commitment and project are relating each other in this decision-making. It is consistent with the previous research conducted by Wong (2005), mentioning esclation commitment should include risk as one of its major components. It means that in the process of allocating resources, individuals affected by escalation situations and the project failure risk that happened. Decision making for the production cost allocation becomes inappropriate because of personal factors (commitment escalation) and external factors (risk projects). Cognitive dissonance experienced by individuals in this research is in accordance with the statement of Heilman and Miclea (2016) that differences in understanding of things become inconsistent and encourage individuals to change their beliefs.

\section{Conclusion}

The right allocation of resource decisions plays a role in determining the company's strategy. Individual decision makers often change their rationality because they experience bias and are faced with high-risk conditions. The decision on resource allocation in this research was examined by examining the causal relationship between escalation of commitment and project risk. The hypotheses testing are carried out by experimental methods and provide empirical findings that escalation of commitment causes inappropriate resource allocation decisions. Inappropriate resource allocation is indicated by decisions that ignore material quality. Other empirical findings show that the higher a risk project causes individual to allocate resources that benefit themselves and ignore material quality. The interaction between escalation of commitment and risk projects will cause the allocation of resources to be inappropriate.

This research has limitation that is the experiments were held in two different classes at different time. The experiments were done twice because when it was only conducted in a Management Accounting class, the number 
of subjects were inadequate. Moreover, the participants did their modules at the end of the class. However, this limitation can be minimized by giving the limited time and some short pauses for each page of the experimental module. This research can be developed by adding the number of participants and giving more pressures in their modules with an extreme conditions.

This research gave the theoritical implication which is allocating resource decision affected by escalation commitment and perception on the project risk, received by the individual. Especially, this research contributes to develop behavioral research in individual decision making. The results of the research supported the previous researches conducted by Ruchala (1999), Chang et al. (2002), Nahartyo and Utami (2014), as well as Wong (2005) that in a high level of escalation of commitment and project risk participants will allocate more in direct labor cost.

This research contributes in management accounting literature by providing the empirical evidence through the experiment. Moreover, this research also contributes to the firm, about the impact of EOC in directing personal perception. Another contribution is to give suggestion how to encourage employees in dealing with projects that can decrease the current financial benefit, yet have the potential organizational benefits in the future.

\section{References}

Arkes, H. R., \& Blumer, C. (1985). The psychology of sunk cost. Organizational Behavior and Human Decision Processes, 35(1), 124-140.

Brockner, J. (1992). The escalation of commitment to a failing course of action: Toward theoretical progress. The Academy of Management Review, 17(1), 39-61.

Chang, J. C., \& Ho, J. L. Y. (2004). Judgment and decision making in project continuation: A study of students as surrogates for experienced managers. A Journal of Accounting and Business Studies, 40(1), 94-116.

Chang, J. C., Ho, J. L. Y., \& Lin, P. (2002). Managers' resource allocation: Review and implications for future research. Journal of Accounting Literature, 21, 1-37.

Curseu, P. L., Schruijer, S. G. L., \& Fodor, O. C. (2016). Decision rules, escalation of commitment and sensitivity to framing in group decision-making: An experimental investigation. Management Decision, 54(7), 16491668.

Dinu, A.-M. (2016). Project risk management - Reasons why projects fail. Quality-Access to Success Journal, 17(3), $208-213$.

Eveline, F. (2010). Pengaruh adverse selection, pembingkaian negatif, dan self-efficacy terhadap eskalasi komitmen proyek investasi yang tidak menguntungkan. Jurnal Akuntansi \& Manajemen, 12(2), 181-198.

Geersbro, J., \& Ritter, T. (2010). External performance barriers in business networks: uncertainty, ambiguity, and conflict. Journal of Business \& Industrial Marketing, 25(3), 196-201. https://doi.org/10.1108/08858621011027786

Heilman, R. M., \& Miclea, M. (2016). Risk seeking preferences: An investigation of framing effects across decisional domains. Cognition, Brain, Behavior: An Interdisciplinary Journal, 20(1), 1-17.

Ho, J.L.Y., Keller, L. R., \& Keltyka, P. (2002). Effects of outcome dan probabilistic ambiguity on managerial choices. Journal of Risk dan Uncertainty. 24(1), 47-74.

Kahneman, D., \& Tversky, A. (1979). Prospect theory: An analysis of decision under risk. Econometrica, 47(2), 263-292.

Kogan, N. (2013). Socialization and cognitive style: A life-span persepective. In P. B. Baltes \& K. Warner Schaie (Eds.), Life-Span Developmental Psychology: Personality and Socialization (pp. 146-179). Orlando: Academic Press.

Merchant, K. A., \& Stede, W. A. Van der. (1997). Management Control Systems: Performance Measurement, Evaluation and Incentives (Second). Upper Saddle River, NJ: Prentice Hall.

Nahartyo, E., \& Utami, I. (2014). Altering rationality : The impact of group support systems and style of leadership. Journal of Applied Management Accounting Research, 12(2), 41-57.

Park, E. H., Ramesh, B., \& Cao, L. (2016). Emotion in it investment decision making with a real options perspective: The intertwining of cognition and regret. Journal of Management Information Systems, 33(3), 652-683. 
Ruchala, L. V. (1999). The influence of budget goal attainment on risk attitudes and escalation. Behavioral Research in Accounting, 11, 161-191.

Simon, H. A. (1995). A behavioral model of rational choice. The Quarterly Journal of Economics, 69(1), 99-118.

SINDONEWS.COM. (2018, September 12). Banyak UKM Tumbang di Tahun Pertama, Ini Penyebabnya. SINDONEWS. Retrieved from https://jabar.sindonews.com/read/1238/1/banyak-ukm-tumbang-di-tahunpertama-ini-penyebabnya- 1536512942

Soman, D. (2001). The mental accounting of sunk time costs: why time is not like money. Journal of Behavioral Decision Making, 14(3), 169-186.

Staw, B. M. (1997). The escalation of commitment: An update and appraisal. In Z. Shapira (Ed.), Organizational Decision Making (pp. 191-215). New York: Cambridge University Press.

Tan, H., \& Yates, J. F. (1995). Sunk Cost Effects : The Influences of Instruction and Future Return Estimates, 63(3), 311-319.

. (2002). Financial budgets and escalation effects. Organizational Behavior and Human Decision Processes, 87(2), 300-322. https://doi.org/10.1006/obhd.2001.2967

Tvede, L. (1999). The psychology of finance. (First edit). Chichester: John Wiley and Sons.

Whyte, G. (1993). Escalating commitment in individual and group decision making: A prospect theory approach. Organizational Behavior and Human Decision Processes, 54(3), 430-455.

Wong, K. F. E. (2005). The role of risk in making decisions under escalation situations. Applied Psychology, 54(4), 584-607. 